\title{
'Madmen, womanizers, and thieves': moral disorder and the cultural text of refugee encampment in Kenya
}

\author{
Hanno Brankamp
}

Introduction

An unmistakable link seems to tie representations of spaces and populations to methods of governance. Refugee camps in Kenya have evoked spectacular imaginaries as 'dangerous sanctuaries' (Lischer 2006), 'hotbed[s] of intrigue' (Crisp 2000: 619), and sites of humanitarian crisis with a 'lack of normal social structures' (Bartolomei et al. 2003: 87). Over the last years, the spectre of terrorist infiltration has created an additional layer of fear over insecurity, territorial disintegration and loss of state control. On 6 May 2016, Kenya's government responded with the decision to begin closing down the Dadaab camps, a contentious process which it has yet to complete. ${ }^{1}$ Humanitarian organizations reiterated the enduring vulnerabilities and protection needs of encamped refugees, and thus justified their obligation to ensure the continuation of existing aid programmes. ${ }^{2}$ This cognitive divide is reflected in popular perceptions among ordinary Kenyan citizens, many of whom recognize the need to relieve human suffering but voice concerns about the socio-economic and security implications of prolonged hospitality for people on the move (IRC and Twaweza 2018).

Despite the political rifts these contending narratives lay bare, they are infused with shared preconceptions about the social and moral lives of refugees as markers of difference. If camps are political technologies of care and control designed to contain 'undesirables' (Agier 2011) and to produce 'spatial effects of immobility, exclusion, and exception' (Brankamp 2019: 67), what constitutes their everyday cultural text is an entrenched vocabulary of 'otherness' and moral disorder. This article examines the discursive practices that write, revise and enact the content of this text in Kakuma, one of the city-sized camps in Kenya's northwestern Turkana county. While the study is based on empirical material from Kakuma, its findings resonate beyond this specific context. It illustrates that portrayals of (un)deservingness, danger and 'infrahumanity' are not limited to racialized encounters between refugees and white-majority societies in the global North (Mamadouh 2012; Holmes and Castañeda 2016; Mayblin 2017); similar

Hanno Brankamp is a lecturer in Human Geography at King's College London. The fieldwork for this article was conducted while the author was a doctoral student at the School of Geography and the Environment, University of Oxford. Email: hanno.brankamp@kcl.ac.uk

${ }^{1}$ Kenya's State Department of Interior announced the closure of the Kakuma and Dadaab camps within three months. Later, the Cabinet Secretary at the time, Joseph Ole Nkaissery, clarified that the closure would affect only Dadaab.

${ }^{2}$ On 9 May 2016, UNHCR launched an appeal to prevent camp closures (see < http://www. unhcr.org/57308e616.html>).

(C) International African Institute 2021. This is an Open Access article, distributed under the terms of the Creative Commons Attribution-NonCommercial-NoDerivatives licence (http://creativecommons.org/ licenses/by-nc-nd/4.0/), which permits non-commercial re-use, distribution, and reproduction in any medium, provided the original work is unaltered and is properly cited. The written permission of Cambridge University Press must be obtained for commercial re-use or in order to create a derivative work. 
sentiments saturate the relations between citizens and non-citizens in many African societies. Paradoxically, the article finds that presuppositions of 'otherness' are often most pronounced among professionals who are officially tasked with managing, protecting and assisting refugees, such as national and international staff of humanitarian agencies, police forces and government officials, all of whom are subsumed here under the name 'camp administrators'.

Kakuma camp was built in 1992 in response to influxes of refugees during the second Sudanese civil war (1983-2005). It started as a Southern Sudanese-majority camp, but currently hosts 148,000 displaced people from eighteen nations, including South Sudan, Somalia, Sudan, Democratic Republic of Congo, Burundi, Ethiopia, Uganda, Rwanda and Eritrea (UNHCR 2018), with each group comprising yet more ethno-linguistic diversity. Since its inception, Kakuma has become one of the largest and longest-running camps on the African continent. Its geographical location in Kenya's northern periphery compounds popular fears of 'foreign' refugees with existing notions of 'cultural otherness' ascribed to Turkana nomads as precarious Kenyan citizens (Meiu 2019). Ohta notes that the arrival of refugee 'strangers' three decades ago had lasting effects on socio-economic dynamics in the area and that Turkana communities themselves 'faced completely new experiences with the emergence of the refugee camp' (2005: 228). However, Turkana have not always treated refugees as 'others'; they have often regarded them convivially as motors of development, trade and employment (Perouse de Montclos and Kagwanja 2000; Sanghi et al. 2016). Despite tales of economic prosperity and integration, less hopeful depictions of refugees as objects of compassion and sources of insecurity loom large as explanatory frames among humanitarian organizations, Kenya's government and the general public. Official communications and reports tend to foreground concerns for refugee protection and national security but eclipse unofficial interpretations of camp life and refugeeness that have gained currency on a local scale. Searching for this 'cultural text' means inevitably attending to unwritten and subliminal forms of knowledge that likely digress from what is usually deemed acceptable to articulate in wider public discourse, not least in the offices of aid agencies. This look behind official rhetoric enables unabridged insights into the self-conceptions of camp administrators and collective understandings of 'others' that confer legitimacy on their everyday actions.

My argument is that camp administrators routinely engage in regimes of knowledge that culturally tarnish the spaces and refugees under their authority, and that are riddled with unequal power relations. This interplay between imaginaries of difference, racialized stereotypes and power hierarchies in the camp is highly reminiscent of a colonial order in which administrators discursively produced colonized subjects as paradoxically childlike and dangerous, eroticized and uncivilized, loyal and capricious, and in need of civilizing reforms (Kothari 2006: 237; Sander 1985; Mudimbe 1988). While camp administrators in Kakuma shared many preconceptions, their respective positionalities - as police officers or aid workers, 'foreigners' or Kenyans, and racialized as white or black - would also account for occasional divergence. Government officials, police officers and most aid workers were Kenyan citizens, with white EuroAmericans representing a small minority alongside humanitarians from other African countries, the Middle East and Asia. However, the inherent slippage between culturalist discourses and the identities of those who engaged in them 
defied neat categorizations. This article places particular emphasis on local 'regimes of knowledge' that rely on imaginations of 'otherness' and offer culturalist interpretations of encampment. The circulation of these discourses spins a web of fantasies and facts that engenders the imaginative geography of the camp and affirms that 'a regime of exchange exists between the imaginary and the real' (Mbembe 2017: 130).

Three tropes are particularly noteworthy in Kakuma. The first depicts refugees as crooks whose presumed dishonesty and proclivity to crime have to be constantly monitored and contained. The second foregrounds hypersexualization, promiscuity, homosexualization and 'sexual deviance' among refugees that are seen as corroding Kenya's moral fabric. The third trope portrays refugees as essentially 'mad' and 'uncivilized', resulting both from their traumatic experiences of conflict and from their ostensibly primordial cultural dispositions. The normalization of these cognitive frames among camp officials has established refugees in Kakuma as devious subjects who require special pedagogical intervention and separation from the rest of society. Rather than negating political agency altogether, these tropes then demonstrate in the eyes of many that refugees possess the wrong kind of agency. This article contributes to growing debates on the imaginative dimensions of humanitarianism and refuge (Rajaram 2002; Nyers 2006; Balaji 2011; Malkki 2015; Olivius 2016; Cox et al. 2019) while supporting a broader agenda of incorporating postcoloniality into contemporary analyses of forced migration and asylum (Tascón 2002; Mayblin 2017; Davies and Isakjee 2019). While Africanist scholars have provided insights on collective refugee imaginaries of humanitarian geopolitics (Turner 2004), diaspora life (Ikanda 2018b) and citizenship (Daley et al. 2018), few studies have focused on the reverse gaze of aid workers and administrators using imaginative discourses to make sense of camp life and displacement. The thrust of this article was inspired by a Kenyan humanitarian worker who claimed that the most pressing issue in Kakuma was neither terrorism nor humanitarian emergency but an underlying state of moral degeneracy and disorder, which he blamed on the presence of 'madmen, womanizers, and thieves'. ${ }^{3}$

This study is based on ethnographic research conducted in Kakuma camp between July 2016 and September 2017. Fieldwork involved participant observation, informal conversations and semi-structured interviews with over 110 interlocutors from aid agencies, the police and local government, Turkana residents and refugees. Depending on each respondent's preference, interviews and conversations were conducted in English, Kiswahili or Arabic. Living on the premises of the Lutheran World Federation (LWF) - a faith-based aid organization - facilitated comprehensive access to staff and allowed for detailed understandings of their off-stage behaviours, casual discourses and everyday forms of 'othering' that underpin this article.

\section{Dominant narratives: security threats or objects of compassion?}

In a 2017 speech before IGAD (Intergovernmental Authority on Development) heads of state in Nairobi, President Uhuru Kenyatta alleged that Kenya's

\footnotetext{
${ }^{3}$ Kakuma, 19 August 2016.
} 
refugee camps had lost their humanitarian character; instead, they 'facilitate agents of terror and destruction', ${ }^{4}$ For him, encampment was:

a protracted situation characterized by hopelessness that easily feeds environmental destruction; ... insecurity; radicalization; criminality; and allows terrorist operatives to exploit it for their operational efforts.

Ten months earlier, on 6 May 2016, Kenya's government had first announced its decision to close the Kakuma and Dadaab refugee camps, citing concerns for national security and, in subsequent statements, the state's priority to protect its own citizens.

While more resolute than ever before, this latest bout of securitization of asylum seekers and refugees was not unprecedented. During Daniel arap Moi's presidency, state-sponsored political rhetoric linked refugees not only to influxes of illicit firearms into Kenya but also - following the 1998 embassy bombings in Nairobi and Dar es Salaam - to a growing terrorist threat (Mogire 2009: 18). Regionally, this resonated with existing fears of 'refugee warriors' who were thought to imperil the internal security of African states (Zolberg et al. 1989; Okech 2015). ${ }^{5}$ After the attacks on Nairobi's Westgate Mall in 2013, Kenya's camps received even further negative attention as the government claimed that at least one of the perpetrators had lived in Kakuma while plotting the attack (Bii 2013; Straziuso and Odula 2013). A 2011 surge in abductions and deadly attacks with grenades and improvised explosive devices (IEDs) in Dadaab afforded the camps domestic and international notoriety (Mukinda and Nyassy 2011; BBC 2012) and firmly established them in Kenya's collective imagination as a proverbial 'womb of terror' (Okari 2016). In particular, Somali refugees were systematically blamed for destabilizing the imagined peace and cohesion of a country that already had a history of social divisions and political strife (Mwangi 2019). Kenyans from different walks of life often reproduced xenophobic soundbites that politicians had broadcast over the years, including claims that 'camps shelter terrorists' or 'refugees can't expect hospitality while killing Kenyans'. ${ }^{6}$ Although these beliefs were not representative of Kenyan society as a whole, there was a noticeable surge in this rhetoric following the Westgate attack. But camps and refugees have occupied a distinctive place in Kenya's national imagination for even longer. Located in the farthest corners of the country, the camps lie outside the imagined boundaries of Kenya's territorial heartlands, in areas historically associated with cattle rustling, border disputes and secessionist insurgency, and fraught with ambiguous loyalties of local residents (Lind 2017; Weitzberg 2017).

Humanitarian organizations framed refugees in Kenya in starkly different, although no less evocative, terms. When the government ordered the camps to be shut, twelve major aid agencies issued a joint statement that warned of an

\footnotetext{
${ }^{4}$ Opening speech at IGAD Assembly of Heads of State and Government on Durable Solutions for Somali Refugees, Nairobi, 25 March 2017.

${ }^{5}$ Until the Comprehensive Peace Agreement in 2005, Kakuma was a rear base for the Sudanese People's Liberation Army (SPLA) (Jansen 2018).

${ }^{6}$ Taken from conversations with a hairdresser and an IT consultant respectively, Nairobi, June 2016.
} 
impending 'humanitarian catastrophe', should the authorities implement the closure. $^{7}$ The organizations emphasized the continuing vulnerabilities of women, children and unaccompanied minors in particular, and the protection risks they would face if involuntarily returned to their countries of origin. In textbook fashion, this advocacy campaign hinged on notions of compassion and refugee victimhood (Malkki 1996; Rajaram 2002), while supposedly reminding Kenya's state of its protection responsibilities under international law. Rather than dismantling constructed binaries of 'us' and 'them', which also underpinned images of 'refugee terrorists', aid agencies reinscribed a kindred opposition that deemed the displaced civilizationally inferior, unequal and dependent (see Fassin 2011).

Humanitarian appeals for more compassionate policies ran the risk of perpetuating implicit understandings of refugees as 'out of place' in Kenyan society. Order and disorder are socially constructed as separate and mutually exclusive spheres, whereby 'the other of order is ambiguity, chaos and indeterminability' (Turner 2004: 230; Nyers 2006). Refugees are embodiments of this imagined deficit of order; they have been severed from their places of origin, unmoored from a comforting 'national order of things' (Malkki 1995), and represent its 'constitutive outside' (Soguk 1999: 51). While the figure of the refugee as security threat is typically characterized as unsavoury, 'anti-civilizational' and a disruption to modern society, the refugee as object of compassion is imagined as premodern and uncivilized and in need of being nurtured and protected, despite presumed moral imperfections (see Duffield 2005). Mayblin argues that this dual exclusion from moral and political equivalence with the rest of humanity marks refugees and asylum seekers as 'people out of place in the spatial organisation of modernity' (2017: 37). The dominant narratives of threat and compassion are both expressions of misgivings about the placement of refugees in the hegemonic moral universe of contemporary Kenyan society and global modernity. Refugeeness is therefore perceived not only as a crisis of citizenship and the national order of things but, fundamentally, as an unsettling state of 'moral disorder'.

\section{Moral disorder: constructing cultural difference and 'otherness' in Kakuma}

When asked about security in Kakuma, a Kenyan UNHCR protection officer sighed with palpable frustration and cautioned me that 'the camp is another jungle altogether, it's another jungle'. ${ }^{8}$ Sensing my perplexity, he continued without further prompting: 'We are dealing with refugees here - one, people that do not understand the law; two, people that do not understand order, you see?' Different shades of this sentiment were not uncommon in the camp, especially among administrators tasked with enforcing laws and providing essential services. However, what the protection officer articulated was not just his

\footnotetext{
${ }^{7}$ On 11 May 2016, twelve aid agencies in Kenya, including World Vision, Oxfam, LWF, the Danish Refugee Council and the Refugee Consortium of Kenya (RCK), released a joint statement to urge the government to reconsider the closure of refugee camps.

${ }^{8}$ Interview with UNHCR protection officer, Kakuma, 20 July 2017.
} 
calculated fear of crime, terrorist forays, or the disintegration of social structures among the encamped. The remarks rather suggested a more deep-seated unease, if not fascination, with the socially imagined otherness and incommensurable cultural difference of 'primitive' refugees who left the camp in 'moral disorder'.

Questions of morality feature prominently in refugee camps and numerous scholars have observed the emergence of place-specific codes of piety, virtue and transgression among the displaced (Turner 2010; Malkki 1995; Horst 2006; McConnachie 2014). In Lukole camp in Tanzania, Turner noted that refugees employed a moral vocabulary to make sense of the changing class, gender and intergenerational dynamics that accompanied their prolonged displacement (Turner 2010: 83). Malkki showed how Hutu refugees resisted local integration by reimagining the camp as a place of moral purity that elevated 'refugeeness' as a positively distinct identity from surrounding host communities (Malkki 1995). In Kakuma, a comparable vision of the camp as a unified moral community is much harder to discern, although the camp is uniquely fragmented into a panoply of social and ethnic identity groups with distinctive moral codes. ${ }^{9}$ Administrators working for aid agencies and the Kenyan state, however, have internalized their own cognitive foils through which they read the social landscape, everyday occurrences and power asymmetries in the camp, while crucially situating themselves within them. In a sense, this constitutes an inversion of the rumours, conspiracies and fictive rationalities that Turner found among refugees in Tanzania (Turner 2004: 239). Tropes and social imaginaries in Kakuma are attempts to rationalize refugee encampment and resolve cognitive dissonances between officially received knowledges and real interpersonal encounters. Charles Taylor argues that social imaginaries characterize 'the ways in which people imagine their social existence', their relationships with and expectations of collective others, and 'the deeper normative notions and images that underlie these expectations' (Taylor 2002: 106). Rather than a fixed set of ideas, social imaginaries constitute a repertoire of shared understandings about the world, cultural belonging and the self that are constantly being reworked through practice (Taylor 2002; Hall and Lamont 2013: 57). The existential ruptures of displacement have often resulted in a search for more stable and recognizable meanings among refugees and administrators through imagination, especially as 'imagining always goes beyond what the world actually is' (Jackson 2008: 72). Even though social imaginaries in Kakuma - like rumours - have neither definite authorship nor origin, they hinge on the illusion of their own 'natural' validity and are assembled from the vestiges of a colonial pedagogy of difference.

Refugee camps are habitually constructed as civilizational antipodes to their outside, which 'reproduce orientalist mappings of the world that deem some people incapable or unworthy of citizenship' (Rygiel 2012: 808). Humanitarianism itself was imprinted by 'modernity' and its belief in engineering progress and spreading civilization (Barnett 2011: 21). Camps thus rearticulate an institutional-cumimaginative divide that also separated colonial native reserves and colonized subjects from legitimate citizens and the modern state (Mamdani 1996). In this Manichean binary, designated spaces of civility were defined in opposition to contorted mirror

\footnotetext{
${ }^{9}$ Jansen (2018) provides an introduction to socio-cultural diversity and social norms in the camp.
} 
images of their supposedly uncivilized and therefore inferior 'other' (Mudimbe 1988; Said 1994; Mbembe 2017). As Bauman notes, 'otherness' is shorthand for a series of socially constructed dichotomies that are key for 'the practice and the vision of social order' (1991: 14). Postcolonial thinkers have demonstrated that otherness is a highly racialized notion that reinforces the symbolic boundaries between the norm of a hegemonic white modernity and the purportedly 'primitive' cultural backwardness of black colonized 'others' (Hall 1997; Bhabha 2004; Sithole 2020). Gilroy understands this othering of blackness through a system of 'infrahumanity' - a hierarchization in which some people are less human than others (2004: 22). Deploying even banal images of 'the other' means discursively enacting a form of domination that is bound up with broader structures of unequal power. Since European colonization, the whole of Africa was imagined as a spatial manifestation of difference onto which the fears, fantasies and disreputable desires of colonialists could be projected (Mbembe 2017: 49). Refugee camps today occupy a similar symbolic role as microcosms of 'otherness' on a global scale. Olivius contends that camps are routinely depicted as 'anarchical, primitive and precivilizational context[s] where refugees act in a purely self-interested way' (2016: 284). Despite the fact that most aid workers and camp officials are national citizens of global South countries - where most refugees are hosted - the racialized Western-centric gaze of humanitarianism prevails and, furthermore, is infused with locally intelligible readings of cultural difference, belonging and (im)morality (Balaji 2011; Benton 2016).

Many camp administrators in Kakuma did not seem to conceive of refugees as the primary purpose of the aid operation, but as a nuisance to be monitored and occasionally 'disciplined'. During a headcount in 2016, a Congolese UNHCR officer vented his frustration at how disruptive refugees were to aid delivery and cautioned: 'If you don't organize these people, they will disturb the whole process. ${ }^{10}$ Quotidian depictions of this kind render the camp a space of intervention and work 'as a regime of knowledge, a systematic, disciplined system of power' that not only naturalizes collective imaginaries but crucially produces the figure of the refugee as 'other' (Lahiri 2003; Haldrup et al. 2006: 175). The imaginaries that undergird this place-specific regime of knowledge, however, are not mere by-products or effects of the camp as a technology: instead, they produce the camp by performing, reproducing and vindicating the power relations of difference that constitute its functional core. Imaginaries about refugees thereby circulate and diffuse across blemished social landscapes and affect 'how myriad agents feel, think, and act' (Wacquant and Slater 2014: 1275) while helping officials and aid workers 'to maintain the authoritative distance necessary to govern' (Kothari 2006: 250).

However, in contrast to prevalent humanitarian narratives, refugees in Kakuma are generally not framed as lacking agency, speech or individuality (Soguk 1999: 243; Malkki 1996; Rajaram 2002) but as moral strangers and incendiaries - subjects endowed with the wrong kind of agency who are therefore in need of sociocultural and physical containment. Three tropes in particular are widespread within the camp: refugees as criminals and crooks; refugees as sexually deviant and idle; and refugees as 'mad' and 'uncivilized'. What permeates these three social imaginaries is their joint emphasis on (im)morality as a marker of difference

\footnotetext{
${ }^{10}$ Kakuma, 4 October 2016.
} 
that legitimizes refugee encampment as a necessary measure to insulate society from the moral disorder that is imagined to reign inside the camp.

\section{Street-smart criminals and crooks}

There was an unspoken understanding in Kakuma that anybody who works in the camp for long enough becomes attuned to the 'disingenuous' behaviour of refugees. Diplomats, senior UN officials, rights advocates and academics, however, were thought of as too naïve and unreasonably trusting towards refugees. 'If you are not intelligent, you can't manage the Somalis,' claimed a Kenyan LWF official on multiple occasions; he warned about the deceptive nature of camp occupants, while also professing his own ability to see through their 'devious' tendencies and charades. ${ }^{11}$

The list of undesirable activities in Kakuma was long and included informal trade in corrugated iron, illicit housing sales, the fabrication of insecurity claims for resettlement, bootlegging home-brewed alcohol and pilfering food. The buying and selling of food ration cards, for example, had resulted in the recent introduction of biometric technology. Several authors have tried to tease out what drives these activities, explaining them as methods for coping with resource scarcity and the harsh conditions of camp life (Harrell-Bond 1986; Jansen 2008; Ikanda 2018a) or as reactions to aid bureaucracies with limited downward accountability (Kibreab 2004). Jansen argues that 'cheating' in the camp is best understood as a 'form of identity politics or impression management' in a system mainly based on self-portrayal for accessing resources (2008: 577). Likewise, resettlement eligibility is determined through hierarchies of protection need that encourage some to simply conform to 'ever-moving categories of suffering' (Ikanda 2018a: 593). Kakuma's police commander lamented the profusion of 'self-inflicted crimes in which someone decides to stage manage a crime with the intention of getting resettlement'. ${ }^{12}$

Social imaginaries of refugee crookedness and criminality are key to performing the discursive work of those administering the camp. Horst argues that the seemingly opposing stereotypes of refugees as 'cunning crooks' and 'vulnerable victims' influence the ways in which aid workers perceive and interact with them (2006: 93-4). Camp bureaucracies are by no means impersonal apparatuses - a senior UNHCR official joked that 'sometimes, people believe humanitarians are people of a different kind, with higher morals and ethical standards. Of course, sometimes the opposite is true. ${ }^{\prime 3}$ But while aid workers may be the most typical camp administrators, local government officials and police officers equally engage with refugees on a daily basis. For many there was no doubt that a large proportion of the refugees in Kakuma camp were fraudsters who took advantage of international aid and Kenyan hospitality. Among Kenyan bureaucrats and officers this often led to attempts at 'saming' refugees with the aim of relativizing the distinctive identities on which claims of resettlement and protection were made. Schor notes: '[I]f othering involves attributing to the objectified other a difference that serves to legitimate her oppression, saming denies the objectified other the right

\footnotetext{
${ }^{11}$ Kakuma, 2 March 2015.

${ }^{12}$ Interview, Kakuma, 2 March 2017.

${ }^{13}$ Informal conversation, Nairobi, 16 June 2017.
} 
to her difference' (1989: 45). In the camp, saming was intimately tied up with, and even existed alongside, processes of othering. Many Kenyan police officers or aid agency employees showed misgivings about the ease with which refugees, especially Somalis, seemed to invite sympathy, access resources and gain settled status in wealthy countries of the global North. As a former camp manager put it:

What I can say is, when it comes to the Somalis, they are very difficult. Somalis are very difficult to deal with, because they are very cunning. It is easy for them to hold citizenship of even five countries at the same time. ${ }^{14}$

Many Kenyans regarded their country as aligned more closely economically and geopolitically to Europe and North America than most refugee-producing states, but felt that they were unfairly denied the advantages of flexible citizenship. Further, the transnational global connections of refugees were taken as reasons to question their genuine vulnerability and eligibility for aid. Neatly woven into this imaginary is the lasting suspicion towards Kenya's own ethnic Somalis, whose 'ambiguous citizenship' (Scharrer 2018) has long put their claim to local belonging in doubt. The former camp manager continued:

[T]hey are very opportunistic, they are very opportunistic! Immediately when you start resettling them, you will [also] end up resettling [Kenyan] Somalis from even Garissa.

Moreover, the near ubiquitous mantra that 'few Somalis will tell you the truth' was locally complemented by the conviction that 'the [South] Sudanese are absolute criminals' ${ }^{15}$ In fact, distrust and suspicion have long existed in Kenyan camps, where UNHCR has considered both Somalis and South Sudanese as particularly 'difficult populations' from the beginning (Hyndman 2000: 130). Drawing from this widely held belief, police officers in Kakuma felt especially concerned that refugees were playing a double game of appealing to white donors and humanitarian advocates, while revealing their 'true' criminal side only to Kenyan aid workers and police officers. Marcus, a thirty-year-old policeman, illustrates this allegedly false self-presentation in Kakuma's majority-Dinka area of 'Hong Kong':

There is no good or bad youth in Hong Kong. They are all bad, thieves and thugs. When the wazungu [white people] show up in their Landcruisers, refugees shout 'Our rights, our rights!', but for us Africans there is no such thing. When we [the police] come to Hong Kong they throw stones at our cars and officers. That's how they really are. ${ }^{16}$

The same sentiment was conveyed by an official from Kenya's Refugee Affairs Secretariat (RAS), who alleged that '97 per cent of refugees here are not genuine but look for resettlement or opportunities for crime. Only the remaining 3 per cent have actual refugee claims.' ${ }^{17}$ Pro-asylum arguments were accordingly met with sly amusement or dismissed as revealing 'a soft spot for refugees'.

\footnotetext{
${ }^{14}$ Interview, Nairobi, 23 March 2017.

${ }^{15}$ Conversation with Kenyan aid worker, Kakuma, 2 March 2015.

${ }^{16}$ Conversation, police station, Kakuma, 21 November 2016.

${ }^{17}$ Conversation with senior RAS official, Kakuma, 14 December 2016.
} 
Sustained international aid for Kakuma's refugees was locally received with a mix of incomprehension and gratitude. Although the causal links between refugee life and crime were widely accepted as plausible, the presence of aid organizations also secured livelihoods for hundreds of Kenyan administrators (see Ikanda 2018a: 588-9). Moral duplicity and surreptitious scheming were understood as the crux of the matter. Refugees were not only believed to defraud a complaisant international community, but they were imagined to be deliberately souring Kenya's valued political alliances with Europe and the US by 'forcing' the government's hand on diplomatically sensitive camp closures.

Even though crookedness and criminality were usually ascribed to refugees in their interactions with aid agencies and state authorities, this was accompanied by an underlying fear that their immoral predilections could 'rub off' on Turkana communities, whom many educated, middle-class administrators from southern Kenya regarded as their 'backward' cultural protégés. ${ }^{18}$ During a meeting with refugee leaders, government officials and UNHCR, a Turkana elder struck a different but equally paternalistic tone in describing the impressionable nature, and therefore vulnerability, of local Turkana communities:

I pity my own Turkana people. Most alcohol that the refugees brew in the camp is sold to the Turkana who finish it all. We are the best customers for alcohol from refugees, and it's ruining our people. ${ }^{19}$

However, while relations of refugees with humanitarian workers and police officers were suffused with power imbalances and top-down governance, their dealings with local Turkana communities were often more socially complex. Despite many Turkana sharing or having internalized reservations about refugees as non-citizens, their own precarious inclusion in Kenya's imagined national community was often reason enough to embrace a contingent cultural identification with Somalis, Dinka or Nuer as fellow pastoralists. Kakuma's local chief therefore referred to the refugees as next of kin: '[W]e Turkana are their "grandmother's leg". We need each other, we are one people.'20

\section{Sexual deviance and idleness}

Another trope that fuelled popular imagination in Kakuma camp was the presumed sexual deviance and idleness of refugees. 'Cultural difference' and conflict-related breakdowns of familial bonds were said to be responsible not only for the spread of promiscuous and extramarital relationships, but also for increasing numbers of defilements and rapes in the camp. ${ }^{21}$ Humanitarian interventions are always invested in the policing of the health, bodies and sexuality of beneficiary populations (Hyndman 2000; Fassin 2007) and thus emulate the

\footnotetext{
${ }^{18}$ This repeatedly came to the fore through a blend of overt assertions and off-hand remarks about the supposed 'cultural underdevelopment' of the Turkana and their need for abandoning 'traditional' ways of life.

${ }^{19}$ Turkana elder, Turkana cafeteria, Kakuma, 14 December 2016.

${ }^{20}$ Kakuma's local chief, Turkana cafeteria, Kakuma, 14 December 2016.

${ }^{21}$ Refugee promiscuity would frequently be discussed in conversations among camp security staff.
} 
intimate biopolitics and moral order-making of colonial regimes (Mbembe 2001; Stoler 2002). Of particular concern to aid organizations in Kakuma were the bodily functions of refugees, which were being monitored and targeted to be reformed through campaigns for improved hygiene, HIV/AIDS prevention, bans on early marriage, or sensitization about sexual and gender-based violence (Horn 2010; Kiura 2014). Kakuma was one of the first camps where 'gender programming' was comprehensively rolled out (Ensor 2017: 206). Billboards along the roads conveyed educational messages warning against open defecation, domestic abuse and the detrimental effects of female circumcision. At the same time, gender identity and the sexual orientation of refugees have become increasingly relevant for asylum claims (Spijkerboer 2013; Lewis and Naples 2014). The establishment of a specialized 'gender desk' in Kakuma's police station signalled a growing sensitivity towards gender-based violence, although the appointed policewoman was frequently caught between following official procedure and 'common sense'. ${ }^{22}$

This institutional focus on sexual health and rights masked the fascination many administrators harboured with the sexuality and intimate lives of refugees. Sexuality and desire are structurally embedded in the exercise of power within the camp. As Foucault argues, societal preoccupations with sexuality work as 'a subtle network of discourses, special knowledges, pleasures, and powers' (Foucault 1998: 71; Stoler 1995) that are the organizing principle of public morality. Subliminal forms of knowledge about refugees in Kakuma thus co-produce a particular imaginative moral and symbolic order in the camp. Not unlike exoticized subjects in colonial discourses, the figure of the refugee hereby becomes 'at once an object of desire and derision' (Bhabha 2004: 96) who is judged against the fiction of a superior morality and civilization, but nonetheless spurs the fantasies of those exerting power over them. Wilson, a policeman formerly stationed in Kakuma, was both troubled and fascinated by what he understood as indecent and hypersexual behaviours among refugees:

In Kakuma, those people are especially idle. And when they are idle they tend to fuck a lot, or to be fucked. I talked even to Somali ladies, asking 'Why do you really [get] involve[d] in these things?' They told me, 'You know once I've eaten, there's no work that I do. I'm being fed so my [only] work is to fuck.' You see? These are the things ... actually I stayed [in Kakuma] and got a good knowledge so that if today I would go to serve there again, I know their ways. ${ }^{23}$

In the police officer's eyes, the blanket provision of humanitarian aid - which assuages the livelihood needs of refugees - is one of the primary reasons for this increase in promiscuity, while the warm climate of Turkana and the cultural diversity of the camp were interpreted as equally conducive to 'immoral behaviours'. ${ }^{24}$ Accordingly, the imagined moral decline of camp life was perceived to be partly due to refugees 'keeping their old habits' 25 as well as the result of aid programmes

\footnotetext{
${ }^{22}$ While the officer would legally have to prosecute an abusive parent, she sometimes decided that the occasional caning of children was appropriate parenting.

${ }^{23}$ Interview, Nairobi, 14 January 2017.

${ }^{24}$ Ibid.

${ }^{25}$ Interview with Kenyan LWF staff, Kakuma, 23 May 2017.
} 
destabilizing gender relations, an explanation that Turner also reported from Tanzania (Turner 2010). Imaginaries of 'idleness' and 'sexual deviance' among refugees were therefore inextricably linked in accounting for Kakuma's assumed deficit in morality. The impression that humanitarian organizations were literally fostering population growth in the camp was a matter of occasional controversy among Kenyan administrators but was ultimately looked upon with complacency since the financial bill was footed by wealthier donor countries.

Among the supposed 'old habits' of refugees was their ignorance of women's rights and gender equality. A Kenyan aid worker warned newly arrived refugees about Kenya's progressive laws and cultural values, which look unfavourably on practices such as early marriage. ${ }^{26}$ A police sergeant voiced similar sentiments, stating that refugees 'marry off small girls, and that's how women's rights are violated'. ${ }^{27}$ Olivius reminds us that in many humanitarian discourses 'refugee women are represented as victims of "backward" cultures in need of protection from humanitarian workers, cast in the role as saviors, while refugee men are represented as perpetrators of "uncivilized" masculinities in need of reform' (Olivius 2016: 272; Ngo and Hansen 2013). Hegemonic and subaltern masculinities are thus pitted against each other over the protection of marginalized women; this has historical resonances. The bulk of sexual panics and imaginings in colonial Kenya were similarly the result of social and cultural frictions that arose in moments of intercorporeal encounter and were laced with broader structural inequalities (Anderson 2010: 66). The hypersexualized imaginaries of violently virile refugee men circulated most freely through banter and storytelling. Rashid, a young policeman, recounted with horror a story he had heard of a male Somali lorry driver who was gang-raped by soldiers in South Sudan, leading him to the conclusion that the South Sudanese, including those in the camp, simply 'aren't good people' ${ }^{28}$

Besides boosting fertility rates in the camp, the impact of 'Western' humanitarians on the moral and cultural lives of refugees was believed to go even further. The presence of white aid workers in particular - with their presumed inclination to champion sexual minority rights - was decried as undermining decency and promoting homosexuality in Kenya, where sexual acts between same-sex individuals are prohibited. Again, Wilson explains:

That is also a clip of the problem. Some refugees were even protesting, making it known that it is their right [to be homosexual]. Because there are those people from Belgium, France, they have legalized same-sex marriages. So, you find those people are also here in the camp because the European community has an interest in the refugee camp. That's why you find them forcing those bad morals onto refugees. ${ }^{29}$

This led to an impossible double bind for refugees being seen either as too susceptible to a permissive 'Western' sexual morality or as not 'developed' enough to become fully part of modern Kenyan society and enjoy the protection of the host state.

\footnotetext{
${ }^{26}$ Gender awareness meeting, Kakuma, 19 August 2016.

${ }^{27}$ Interview, Kakuma, 7 February 2017.

${ }^{28}$ Conversation, Kakuma, 10 February 2017.

${ }^{29}$ Interview, Nairobi, 14 January 2017.
} 
The tension between desire and disavowal underlying these imaginaries is constant, making some camp officials portray refugees as depraved while secretly engaging in sexual relations with them. It was common knowledge in Kakuma that a great number of refugee children had been fathered by police officers, and also that a significant number of officials and humanitarian workers had engaged in casual sex with refugees (see also Buckley-Zistel and Krause 2017; Ferris 2007). A senior government officer - who would usually show contempt for refugees - openly recounted his sexual affairs with Somali women, whom he described as 'exotic' objects of desire: '[T]hey all look the same with the hijab, but when they take it off, their hair is long and curly!' 30 The flipside of publicly performed disdain for the supposed 'immorality' of refugees is this exploitative and sexualizing gaze that reproduces structural power asymmetries on intimate microscales. 'Disavowal', in the words of Stuart Hall, is therefore a 'strategy by means of which a powerful fascination or desire is both indulged and at the same time denied' (1997: 267).

\section{Madness and uncivilization}

The third pervasive trope in Kakuma somewhat encompasses the other two and imagines refugees as inherently 'mad' and 'uncivilized'. Despite internal differentiations that labelled certain refugees as more unruly than others, this imaginary acted as a blanket explanation for the violence, insecurity and 'chaos' that typically feature in scholarly accounts of camps (Crisp 2000; Hyndman 2004). John, a Kakuma police officer, reasoned that 'most refugees have had terrible experiences in their home countries, so now they are "don't carers". ${ }^{31}$ Displacement and warrelated traumas - which many refugees have undoubtedly suffered - were among the most commonly named reasons for their perceived 'unpredictability' and enduring 'madness'. John continued:

Refugees don't respect the police. When we disperse a crowd, they come after you and even insult you. In Kakamega [a county in western Kenya], you won't see that a policeman is being insulted or that someone resists an arrest. Here, if you aren't careful they can even snatch the gun from you. ${ }^{32}$

Invoking insubordination of refugees towards the police was not just a way of confirming their 'otherness'; it also reimagined fellow Kenyans as model citizens (however improbably). Unlike public discourses in which refugees are sometimes depicted as would-be terrorists with an anti-Kenyan political agenda, this characterizes them first and foremost as a pathologized category of humanity. 'Even killing,' an inspector observed with confidence, 'is not a problem to them at all.' ${ }^{33}$ The prolific pathologization of refugees in the camp is hardly surprising, considering the imaginative power that disease, infection and trauma continue to have in current debates on migration (Harper and Raman 2008; Taylor 2013) and in longer colonial discourses (Vaughan 1993; Fanon 2004). Pupavac notes

\footnotetext{
${ }^{30}$ Conversation, Kakuma, 10 February 2017.

${ }^{31}$ Conversation, Kakuma, 7 February 2017.

${ }^{32}$ Ibid.

${ }^{33}$ Interview, Nairobi, 14 January 2017.
} 
that deterministic traits are embedded in humanitarian operational cultures and '[construct] war-affected populations as traumatized and subject to psychosocial dysfunctionalism' (2002: 489). Charles Bukowski distinguishes between 'ordinary madness' - everyday predicaments and frustrations - and 'pathological madness', which is more existential in nature and fundamentally dislodges our being in and from the world (cited in Jackson 2008: 58; Sander 1985). The 'madness' associated with refugees is often seen as pathological and it is thus no wonder that Kenya's refugee camps have been described as 'highly dysfunctional entities' (Crisp 2000: 624). However, while ascriptions of antisocial and 'immoral' behaviours to war-related trauma are widespread, notions of social dysfunctionality can also attain more culturalist and racialized overtones. Once again, John explained:

I think it's because of the laws they are used to. Their laws are different from our laws. Also, they were brought up fighting with wars raging around them. Culture is another factor - our culture is different from theirs. ${ }^{34}$

Although experiences of war and conflict are rationalized as the major causes of social and moral disorder in Kakuma, culture in its most essentialized form is constructed as the 'natural' spring from which lawlessness flows. Kakuma's police chief was convinced that South Sudanese refugees 'are violent by nature and they aren't used to functioning laws'. ${ }^{35}$ This reminds us of the imagined figure of the 'barbarian' that Duffield characterizes as an antagonist to modern Western civilization, which he 'despises, covets and constantly fights' (Duffield 2005: 148). Subscribing to similarly disparaging imaginings, a government official in Kakuma described the ordering principle of the whole camp as 'politics of the head bone', which means that 'you knock people down with your head and fist before thinking' ${ }^{36}$ Informing this discursive othering was the reproduction of notorious colonial stereotypes of African 'savagery' that pervaded the minds and logics of many camp administrators, who sometimes accused refugees of cannibalism, sodomy and witchcraft. ${ }^{37}$

Despite the predominant role Kenyan officials and aid workers played in shaping this discursive field, white humanitarians seemed to thrive at least as much on spectacular stories that could affirm their racialized fears about 'darkest' Africa. The imagined moral and cultural predisposition of African refugees presented a convenient explanatory frame for recurrent challenges in managing the operation, acquitting humanitarians of structural responsibility while locating any shortcomings in the disagreeable lives of the displaced. A white woman aid worker was under the racist impression that certain South Sudanese refugees were a major hindrance to the smooth functioning of the humanitarian enterprise:

I don't mean this in a derogatory way, but the Lotukos are fucking bush people that don't even know how to use a toilet. There are all sorts of innovative projects, but we can't even fucking make them stop FGM-ing themselves, so how are they going to learn more complex stuff? $?^{38}$

\footnotetext{
${ }^{34}$ Conversation, Kakuma, 7 February 2017.

${ }^{35}$ Conversation, Kakuma, 8 December 2016.

${ }^{36}$ Conversation, Kakuma, 17 February 2017.

${ }^{37}$ Administrators would often reminisce about refugee involvement in such acts.

${ }^{38}$ Conversation, Kakuma, 15 August 2016.
} 
While refugee 'crooks' supposedly undermine humanitarian assistance out of ill will and for personal profit, the aid worker's racialized account singles out the Lotuko as specifically uncivilized agents of disorder, unworthy of receiving aid. Supposedly irrepressible, less-than-human or animalized behaviours of certain refugees rendered Kakuma, in the words of a sympathetic African aid worker, 'the worst location for white UNHCR staff'. ${ }^{39}$ A despairing UNHCR officer maintained at a Kakuma field post: '[I]f we didn't have these fences here, we wouldn't be able to manage these people. I knew that from day one.' 40 The discursive production of the refugee figure as 'mad' and 'uncivilized' is thereby inseparable from social imaginings of their 'sexual deviance' or 'crookedness' as concrete expressions of infrahumanity and dehumanization. Together, these imaginaries discursively legitimize the organisational and moral foundations of the camp as a humanitarian civilizing mission: namely, a space of 'social and cultural transformation and modernization' (Olivius 2016: 281).

\section{The cultural text of refugee encampment}

Representations of morality, contagion and peril have the power to socially inscribe stigma onto particular spaces and, by extension, those who inhabit them (Wacquant 2007). Social imaginaries of 'crookedness', 'deviance' and 'madness' in relation to Kakuma's refugees amount to more than just a discursive field, taking centre stage in performing everyday relations of power. Speaking about widespread cultural preconceptions about the camp, an adviser to the governor of Turkana concluded: '[I]t's stereotypes, but they affect security here very much.' ${ }^{41}$ Forms of social stigma pervade institutional practices of humanitarian agencies and the Kenyan state in Kakuma's aid operation. Containment, which has received much attention as a geopolitical means of impeding refugee mobilities (Jaji 2012; Hyndman and Giles 2016), must therefore also be understood as creating a buffer for the moral bordering of refugees from both Kenyan and international society. This two-pronged exclusion from national and global modernity - of which humanitarianism is a key ideology and practice - enables the convergence of various imaginaries of difference and infrahumanity. Colonial representations of otherness are being constantly 'mobilized, reworked and mediated through ideologies, individuals and institutions in the postindependence period' (Kothari 2006: 238). Thievery, sexual fears and pathologized 'madness' continued to be projected onto Africans long after independence, but were simultaneously used to construct new internal 'others' in the postcolonies such as Kenya (Amoko 2001; Anderson 2010). Street-level administrators, who perform the banal work of humanitarian agencies and the state, are always at the forefront of this reworking of cultural imaginations.

Spatial containment and mobility control are part of the same contiguous process of order-making as the moral condemnation of refugees by means of an unwritten cultural text. This cultural grammar can have far-reaching

\footnotetext{
${ }^{39}$ Conversation, Kakuma, 17 January 2017.

${ }^{40}$ Conversation, Kakuma, 4 October 2016.

${ }^{41}$ Interview, Lodwar, 15 May 2017.
} 
consequences for the psycho-social lives of the governed, affecting their encounters with the police, humanitarian officers and social services, fragmenting communities and corroding their collective sense of self worth, while validating negative stereotypes by setting in motion socially 'undesirable' coping strategies (see Wacquant and Slater 2014: 1275). The refugee camp specifically lends itself to being imagined as an enclave of 'otherness': a remote space in which the ideals of humanitarian civility and Kenyan modernity are constantly jeopardized and questioned by the displaced, who are thought of as barely exhibiting acceptable humanity. The invocation of moral disorder and refugee 'backwardness' among aid workers is especially disconcerting because it contradicts morally equalizing ideas of a 'common humanity' that humanitarianism nominally professes (see Feldman and Ticktin 2010).

Kakuma camp is at the same time interpreted through the lens of specifically Kenyan geographies of belonging. Ethnicized identities in the country are generally inscribed with differential 'marks of civilisation' (Lonsdale 2008: 311). These weave a 'system of moral meaning and ethical reputation within a more or less imagined community' (Lonsdale 1996: 132) that distinguishes those who are members from those who are not. Moral belonging is thus spatialized through mapping popular cultural boundaries on Kenya's imagined patchwork grid of ethnic territoriality (Jenkins 2012). Refugees are uniquely 'out of place' in this cultural organization of contemporary Kenya and are excluded not only from citizenship but from ownership claims to ancestral homelands within the bounds of their long-term country of asylum. In Kakuma, despite contestations over national belonging among Kenyan citizens, the discursive positioning of refugees as 'moral strangers', 'uncivilized' interlopers or 'criminals' had the interesting effect of strengthening a new provisional but shared Kenyan identity. The framing of moral disorder contained in the camp constituted a conducive foil through which Kenyan officials and administrators could express their negative imaginings about alien 'others' while inadvertently mending the vestiges of a fractured 'Kenyanness', if only temporarily and conditionally. In Kenya's cultural order of things, Kakuma camp became a surrogate homeland to which refugees were legally bound without being protected through socio-cultural inclusion. A Kenyan government official accordingly asserted at a public gathering in the camp that:

Some refugees who come here think that the compounds they live in are theirs. This land is community property of the Turkana, not private property. No refugee holds his own land as property. The land is ours here.

This categorical exclusion of refugees from Kenya's ethno-territorial mappings was further articulated by a Kenyan humanitarian worker who told a group of refugee youth: 'Hakuna Kongo ama Sudan hapa. Hapa ni Kenya! [This is not Congo or Sudan. This is Kenya!]'

Moral imaginaries about the multifaceted 'otherness' of refugees perform the necessary discursive groundwork of this political exclusion. Everyday images, desires and cultural fears about 'the other' circulate through conversations, innuendos and casual utterances, automatically making grand narratives about the moral geography of the world an intimate part of ordinary life as well. This is not to deflect from the contrasting ways in which refugees themselves imagine 
encampment; rather, it supplements them. Reminiscing about his hopes before arriving in the camp, an Ethiopian refugee said he 'imagined it as a safe place where everybody is living in a secure manner. But, unfortunately, we don't get that. ${ }^{42}$ A Burundian refugee voiced his misgivings about the mistrust that humanitarians, especially Africans, exhibited towards the camp residents: 'Whites are more humane than Africans. Africans don't love each other. I'm unable to express in words the type of indignity they showed me. ${ }^{43}$ While some refugees thereby seek to derive deeper meaning from the social relations they experience in the camp (see Turner 2004; Horst 2006), the banal discourses among the administrators constitute a vivid and constantly evolving counter-imagination.

Popular images of uncivilization and primitivity in sexual, pathological or character terms thus produce an ordering of Kenyan society as seen from the camp, in which citizens and their cultural modernity are protected by containing masses of immoral 'others'. However, this cultural text of encampment is not simply a regrettable side-effect of prolonged aid programmes but is a formative part of the imaginative geography of the camp more widely. An NGO worker mused: '[A]t the end of the day they are just refugees, that's why they are contained in a camp. ${ }^{44}$

\section{Conclusion}

Popular imaginaries of refugee camps in Kenya are often spectacular and dwell on notions of intrigue, threat and permanent crisis. Public discourses depict refugees in the country as potential terrorists or objects of humanitarian compassion: a representational opposition that has framed the Kenyan government's repeated calls for camp closures in recent years. Meanwhile, there has been little recognition of the fact that these narratives are built on common preconceptions about immutable civilizational and cultural differences that are thought to distinguish the encamped from Kenyan society and hinder their inclusion in a global modernity. Beyond constituting geo/biopolitical technologies of 'care and control' (Agier 2011; Jaji 2012), refugee camps are thus socially constructed as microcosmic spaces of pre-modernity, primitivity and enduring otherness.

In Kakuma, this emotive 'cultural text' of humanitarian encampment comes to the fore in particular through everyday discourses and banal forms of 'othering' among camp administrators: aid workers, police officers and government officials. While the aid system itself is based on refugees reproducing categories of vulnerability and deservingness (Jansen 2008; Ikanda 2018a), social imaginaries of criminality, sexual deviance and 'madness' sharpen the categorical boundaries between the deserving and undeserving. This projection of essentialized difference onto refugees characterizes them not only as recipients of temporary protection and material aid but, crucially, as requiring moral advancement and reform. The web of exclusionary knowledge that is thus spun is reminiscent of the pedagogies used to construct and govern colonized subjects (Sander 1985;

\footnotetext{
${ }^{42}$ Interview, Kakuma, 8 March 2015.

${ }^{43}$ Interview, Kakuma, 6 April 2017.

${ }^{44}$ Interview, Nairobi, 12 July 2017.
} 
Kothari 2006; Mayblin 2017). Localized representational practices and regimes of knowledge are thus at least as important for understanding the workings of humanitarian camps as the politics that perpetuate their existence. Upholding the notion of 'moral disorder' is instrumental in rationalizing the immobilization of refugees and simultaneously conjures existential fears about the moral contamination of Kenya. In this way, encampment is reimagined not only as containing a leakage of immorality but also as a spatialized form of moral probation.

Recognition that the camp has not just a political but also an imaginative geography is a valuable addition to the extensive scholarship on camps as institutions of aid. This is especially true for African societies such as Kenya, where encampment has been a persistent feature of politics and everyday life. Different logics and meanings of refugee camps as 'postcolonial entities' (Davies and Isakjee 2019) continue to inform the lives of people who reside and work in them today. Politically, camps are means for delivering aid and holding mobile bodies 'in place'. The cultural work of camps, however, imbues these exclusionary practices with intransigent ideas of belonging and civilizational inadequacy that reinforce the designation of refugees as moral 'others'.

\section{Acknowledgements}

The research for this article was kindly supported by the Economic and Social Research Council (ESRC) and the German National Academic Foundation (Studienstiftung des Deutschen Volkes). Most importantly, I would like to express my sincerest gratitude to all of my interlocutors for their openness, trust and time during fieldwork in Kenya. Patricia Daley and Olly Owen gave incredibly useful feedback on an earlier draft. Lastly, the article has benefited from the generous comments of two anonymous reviewers.

\section{References}

Agier, M. (2011) Managing the Undesirables: refugee camps and humanitarian government. Cambridge: Polity Press.

Amoko, A. (2001) 'The "missionary position" and the postcolonial polity, or, sexual difference in the field of Kenyan colonial knowledge', Callaloo 24 (1): 310-24.

Anderson, D. M. (2010) 'Sexual threat and settler society: "black perils" in Kenya, c.1907-30', Journal of Imperial and Commonwealth History 38 (1): 47-74.

Balaji, M. (2011) 'Racializing pity: the Haiti earthquake and the plight of "others", Critical Studies in Media Communication 28 (1): 50-67.

Barnett, M. (2011) Empire of Humanity: a history of humanitarianism. Ithaca NY: Cornell University Press.

Bartolomei, L., E. Pittaway and E. E. Pittaway (2003) 'Who am I? Identity and citizenship in Kakuma refugee camp in northern Kenya', Development 46 (3): 87-93.

Bauman, Z. (1991) Modernity and Ambivalence. Ithaca NY: Cornell University Press.

BBC (2012) 'Aid workers kidnapped from Kenya's Dadaab camp near Somalia', BBC News, 29 June <https://www.bbc.co.uk/news/world-africa-18644745>. 
Benton, A. (2016) 'African expatriates and race in the anthropology of humanitarianism', Critical African Studies 8 (3): 266-77.

Bhabha, H. K. (2004) 'The other question' in H. K. Bhabha, The Location of Culture. London and New York NY: Routledge.

Bii, B. (2013) 'Police step up security in Kakuma after Westgate attack', Daily Nation, 2 October <http://www.nation.co.ke/news/Police-step-up-security-inKakuma-refugee-after-Westgate-attack/1056-2015788-e01xtp/index.html>.

Brankamp, H. (2019) "OCcupied enclave": policing and the underbelly of humanitarian governance in Kakuma refugee camp, Kenya', Political Geography 71: 67-77.

Buckley-Zistel, S. and U. Krause (eds) (2017) Gender, Violence, Refugees. New York NY and Oxford: Berghahn Books.

Cox, E., S. Durrant, D. Farrier, L. Stonebridge and A. Woolley (eds) (2019) Refugee Imaginaries: research across the humanities. Edinburgh: Edinburgh University Press.

Crisp, J. (2000) 'A state of insecurity: the political economy of violence in Kenya's refugee camps', African Affairs 99 (397): 601-32.

Daley, P., N. Kamata and L. Singo (2018) 'Undoing traceable beginnings', Migration and Society 1 (1): 22-35.

Davies, T. and A. Isakjee (2019) 'Ruins of empire: refugees, race and the postcolonial geographies of European migrant camps', Geoforum 102: 214-17.

Duffield, M. (2005) 'Getting savages to fight barbarians: development, security and the colonial present', Conflict, Security and Development 5 (2): 141-59.

Ensor, M. O. (2017) 'Lost boys, invisible girls: children, gendered violence and wartime displacement in South Sudan' in S. Buckley-Zistel and U. Krause (eds), Gender, Violence, Refugees. New York NY and Oxford: Berghahn Books.

Fanon, F. (2004) The Wretched of the Earth. New York NY: Grove Press.

Fassin, D. (2007) 'Humanitarianism as a politics of life', Public Culture 19 (3): 499-520.

Fassin, D. (2011) Humanitarian Reason: a moral history of the present. Berkeley CA: University of California Press.

Feldman, I. and M. Ticktin (eds) (2010) In the Name of Humanity: the government of threat and care. Durham NC: Duke University Press.

Ferris, E. G. (2007) 'Abuse of power: sexual exploitation of refugee women and girls', Signs: Journal of Women in Culture and Society 32 (3): 575-9.

Foucault, M. (1998) The Will to Knowledge: the history of sexuality. Volume 1. London: Penguin Books.

Gilroy, P. (2004) Between Camps: nations, cultures and the allure of race. London: Routledge.

Haldrup, M., L. Koefoed and K. Simonsen (2006) 'Practical orientalism: bodies, everyday life and the construction of otherness', Geografiska Annaler, Series B: Human Geography 88 (2): 173-84.

Hall, P. A. and M. Lamont (2013) 'Why social relations matter for politics and successful societies', Annual Review of Political Science 16: 49-71.

Hall, S. (1997) 'The spectacle of the "other"' in S. Hall (ed.), Representation: cultural representations and signifying practices. London: Sage.

Harper, I. and P. Raman (2008) 'Less than human? Diaspora, disease and the question of citizenship', International Migration 46 (5): 3-26. 
Harrell-Bond, B. E. (1986) Imposing Aid: emergency assistance to refugees. Oxford: Oxford University Press.

Holmes, S. M. and H. Castañeda (2016) 'Representing the "European refugee crisis" in Germany and beyond: deservingness and difference, life and death', American Ethnologist 43 (1): 12-24.

Horn, R. (2010) 'Exploring the impact of displacement and encampment on domestic violence in Kakuma refugee camp', Journal of Refugee Studies 23 (3): 356-76.

Horst, C. (2006) Transnational Nomads: how Somalis cope with refugee life in the Dadaab camps of Kenya. New York NY and Oxford: Berghahn Books.

Hyndman, J. (2000) Managing Displacement: refugees and the politics of humanitarianism. Minneapolis MN and London: University of Minnesota Press.

Hyndman, J. (2004) 'Refugee camps as conflict zones: the politics of gender' in W. Giles and J. Hyndman (eds), Sites of Violence: gender and conflict zones. Berkeley CA: University of California Press.

Hyndman, J. and W. Giles (2016) Refugees in Extended Exile: living on the edge. London: Routledge.

Ikanda, F. N. (2018a) "Animating "refugeeness" through vulnerabilities: worthiness of long-term exile in resettlement claims among Somali refugees in Kenya', Africa 88 (3): 579-96.

Ikanda, F. N. (2018b) 'Somali refugees in Kenya and social resilience: resettlement imaginings and the longing for Minnesota', African Affairs 117 (469): 569-91.

IRC and Twaweza (2018) Kenya: citizens' perceptions on refugees. Nairobi: International Rescue Committee (IRC) and Twaweza <https://www.twaweza. org/uploads/files/IRC Kenya1806201801.pdf>, accessed 1 December 2018.

Jackson, M. (2008) 'The shock of the new: migrant imaginaries and critical transitions', Ethnos 73 (1): 57-72.

Jaji, R. (2012) 'Social technology and refugee encampment in Kenya', Journal of Refugee Studies 25 (2): 221-38.

Jansen, B. J. (2008) 'Between vulnerability and assertiveness: negotiating resettlement in Kakuma refugee camp, Kenya', African Affairs 107 (429): 569-87.

Jansen, B. J. (2018) Kakuma Refugee Camp: humanitarian urbanism in Kenya's accidental city. London: Zed Books.

Jenkins, S. (2012) 'Ethnicity, violence, and the immigrant-guest metaphor in Kenya', African Affairs 111 (445): 576-96.

Kibreab, G. (2004) 'Pulling the wool over the eyes of the strangers: refugee deceit and trickery in institutionalized settings', Journal of Refugee Studies 17 (1): $1-26$.

Kiura, A. W. (2014) 'Constrained agency on contraceptive use among Somali refugee women in the Kakuma refugee camp in Kenya', Gender, Technology and Development 18 (1): 147-61.

Kothari, U. (2006) 'Spatial practices and imaginaries: experiences of colonial officers and development professionals', Singapore Journal of Tropical Geography 27 (3): 235-53.

Lahiri, S. (2003) 'Performing identity: colonial migrants, passing and mimicry between the wars', Cultural Geographies 10: 408-23.

Lewis, R. A. and N. A. Naples (2014) 'Introduction: queer migration, asylum, and displacement', Sexualities 17 (8): 911-18. 
Lind, J. (2017) 'Devolution, shifting centre-periphery relationships and conflict in northern Kenya', Political Geography 63: 135-47.

Lischer, S. K. (2006) Dangerous Sanctuaries: refugee camps, civil war, and the dilemmas of humanitarian aid. Ithaca NY: Cornell University Press.

Lonsdale, J. (1996) 'Moral ethnicity and political tribalism' in P. Kaarsholm and J. Hultin (eds), Inventions and boundaries: historical and anthropological approaches to ethnicity and nationalism. Occasional Paper 11. Roskilde: International Development Research Group, Roskilde University.

Lonsdale, J. (2008) 'Soil, work, civilisation, and citizenship in Kenya', Journal of Eastern African Studies 2 (2): 305-14.

Malkki, L. H. (1995) Purity and Exile: violence, memory, and national cosmology among Hutu refugees in Tanzania. Chicago IL: University of Chicago Press.

Malkki, L. H. (1996) 'Speechless emissaries: refugees, humanitarianism, and dehistoricization', Cultural Anthropology 11 (3): 377-404.

Malkki, L. H. (2015) The Need to Help: the domestic arts of international humanitarianism. Durham NC: Duke University Press.

Mamadouh, V. (2012) 'The scaling of the "invasion": a geopolitics of immigration narratives in France and the Netherlands', Geopolitics 17 (2): 377-401.

Mamdani, M. (1996) Citizen and Subject: contemporary Africa and the legacy of late colonialism. London: James Currey.

Mayblin, L. (2017) Asylum after Empire: colonial legacies in the politics of asylum seeking. London and New York NY: Rowman and Littlefield.

Mbembe, A. (2001) On the Postcolony. Berkeley CA: University of California Press.

Mbembe, A. (2017) Critique of Black Reason. Durham NC and London: Duke University Press.

McConnachie, K. (2014) Governing Refugees: justice, order and legal pluralism. London and New York NY: Routledge.

Meiu, G. P. (2019) 'Who are the new in Africa' in R. R. Grinker et al. (eds), A Companion to the Anthropology of Africa. Oxford: Wiley.

Mogire, E. (2009) 'Refugee realities: refugee rights versus state security in Kenya and Tanzania', Transformation 26 (1): 15-29.

Mudimbe, V.-Y. (1988) The Invention of Africa: gnosis, philosophy, and the order of knowledge. London: James Currey.

Mukinda, F. and D. Nyassy (2011) 'Al Shabaab kidnap aid workers at Kenyan camp', Daily Nation, 13 October < https://www.nation.co.ke/news/ Gunmen-kidnap-aid-workers-at-Kenyan-camp/1056-1254876-eytmkrz/index. html>, accessed 20 November 2018.

Mwangi, O. G. (2019) 'The "Somalinisation" of terrorism and counterterrorism in Kenya: the case of refoulement', Critical Studies on Terrorism 12 (2): 298-316.

Ngo, B. and S. Hansen (2013) 'Constructing identities in UN refugee camps: the politics of language, culture and humanitarian assistance', Critical Inquiry in Language Studies 10 (2): 97-120.

Nyers, P. (2006) Rethinking Refugees: beyond states of emergency. New York NY and London: Routledge.

Ohta, I. (2005) 'Coexisting with cultural "others": social relationships between the Turkana and the refugees at Kakuma, northwest Kenya', Senri Ethnological Studies 69: 227-39. 
Okari, D. (2016) 'Womb of terror: is Dadaab camp a security threat to the country?', NTV Kenya <https://www.youtube.com/watch?v=ClQUJ7bShVI>.

Okech, A. (2015) 'Asymmetrical conflict and human security: reflections from Kenya', Strategic Review for Southern Africa 37 (1): 53-74.

Olivius, E. (2016) 'Constructing humanitarian selves and refugee others', International Feminist Journal of Politics 18 (2): 270-90.

Perouse de Montclos, M.-A. and P. M. Kagwanja (2000) 'Refugee camps or cities? The socio-economic dynamics of the Dadaab and Kakuma camps in northern Kenya', Journal of Refugee Studies 13 (2): 205-22.

Pupavac, V. (2002) 'Pathologizing populations and colonizing minds: international psychosocial programs in Kosovo', Alternatives 27 (4): 489-511.

Rajaram, P. K. (2002) 'Humanitarianism and representations of the refugee', Journal of Refugee Studies 15 (3): 247-64.

Rygiel, K. (2012) 'Politicizing camps: forging transgressive citizenships in and through transit', Citizenship Studies 16 (5-6): 807-25.

Said, E. (1994) Orientalism. New York NY: Vintage Books.

Sander, G. (1985) Difference and Pathology: stereotypes of sexuality, race and madness. Ithaca NY: Cornell University Press.

Sanghi, A., H. Onder and V. Vemuru (2016) 'Yes' in my Backyard?: The economics of refugees and their social dynamics in Kakuma, Kenya. Washington DC: World Bank.

Scharrer, T. (2018) "“Ambiguous citizens": Kenyan Somalis and the question of belonging', Journal of Eastern African Studies 12 (3): 494-513.

Schor, N. (1989) 'This essentialism which is not one: coming to grips with Irigaray', Differences 1 (3): 38-58.

Sithole, T. (2020) The Black Register. Cambridge: Polity Press.

Soguk, N. (1999) States and Strangers: refugees and displacements of statecraft. Minneapolis MN: University of Minnesota Press.

Spijkerboer, T. (2013) Fleeing Homophobia: sexual orientation, gender identity, and asylum. Abingdon: Routledge.

Stoler, A. L. (1995) Race and the Education of Desire. Durham NC and London: Duke University Press.

Stoler, A. L. (2002) Carnal Knowledge and Imperial Power: race and the intimate in colonial rule. Berkeley and Los Angeles CA: University of California Press.

Straziuso, J. and T. Odula (2013) 'One of Westgate Mall attackers lived in Kenyan refugee camp', Washington Times, 11 November < https://www.washingtontimes.com/news/2013/nov/11/one-westgate-mall-attackers-lived-kenyanrefugee-c/>, accessed 7 February 2018.

Tascón, S. M. (2002) 'Refugees and asylum seekers in Australia: border-crossers of the postcolonial imaginary', Australian Journal of Human Rights 8 (1): 125-39.

Taylor, C. (2002) 'Modern social imaginaries', Public Culture 14 (1): 91-124.

Taylor, R. C. R. (2013) 'The politics of securing borders and the identities of disease', Sociology of Health and Illness 35 (2): 241-54.

Turner, S. (2004) 'Under the gaze of the "big nations": refugees, rumours and the international community in Tanzania', African Affairs 103 (411): 227-47.

Turner, S. (2010) Politics of Innocence: Hutu identity, conflict and camp life. Oxford: Berghahn Books. 
UNHCR (2018) 'Kakuma camp population statistics by country of origin, sex and age group'. Kakuma: United Nations High Commissioner for Refugees (UNHCR).

Vaughan, M. (1993) 'Madness and colonialism, colonialism as madness: rereading Fanon. Colonial discourse and the psychopathology of colonialism', Paideuma: Mitteilungen zur Kulturkunde 39: 45-55.

Wacquant, L. (2007) 'Territorial stigmatization in the age of advanced marginality', Thesis Eleven 91 (1): 66-77.

Wacquant, L. and T. Slater (2014) 'Territorial stigmatization in action', Environment and Planning A 46 (6): 1270-80.

Weitzberg, K. (2017) We Do Not Have Borders: greater Somalia and the predicaments of belonging in Kenya. Athens $\mathrm{OH}$ : Ohio University Press.

Zolberg, A., A. Suhrke and S. Aguayo (1989) Escape from Violence: conflict and the refugee crisis in the developing world. New York NY and Oxford: Oxford University Press.

\begin{abstract}
Kenya's refugee camps have evoked spectacular imaginaries of terrorism and humanitarian crisis. Drawing on everyday discourses and shared knowledges among camp administrators, this article reveals that these geopolitical narratives are underwritten locally by more generalized concerns about the imagined 'otherness' and moral degeneracy of the displaced. Refugees are thus portrayed as criminals and crooks, sexually deviant and idle, as well as 'mad' and uncivilized. Together, these tropes constitute a cultural text of encampment that reproduces postcolonial imaginings of difference and engrains the notion that 'refugeeness' equates to a state of 'moral disorder'. The article is based on ethnographic fieldwork conducted in Kakuma refugee camp in north-western Kenya's Turkana county. It argues that the discursive production of refugees as immoral subjects not only has practical effects for the actions of government officials and aid workers but rekindles a binary colonial mapping of the world into "civilized' and 'uncivilized' spaces. These social imaginaries and banal discourses illustrate that the camp has not just a political but also an imaginative geography. Kakuma camp is hereby doubly excluded: from the modernity that humanitarianism ostensibly embodies and from the imagined moral community of Kenya.
\end{abstract}

\title{
Résumé
}

Les camps de réfugiés au Kenya ont évoqué des imaginaires spectaculaires de terrorisme et de crise humanitaire. S'appuyant sur des discours courants et des connaissances partagées d'administrateurs de camp, cet article révèle que ces récits géopolitiques sont appuyés localement par des préoccupations plus généralisées concernant "l'altérité » et la dépravation morale imaginées des déplacés. Les réfugiés sont ainsi présentés comme des criminels et des escrocs, des déviants sexuels et des oisifs, ainsi que des " fous » et des non-civilisés. Ensemble, ces tropes constituent un texte culturel du campement qui reproduit les imaginations postcoloniales de la différence et instille la notion que «l'état de réfugié » équivaut à un état de " désordre moral». Cet article s'appuie sur des travaux ethnographiques menés sur le terrain dans le camp de réfugiés de Kakuma, situé dans le nordest du Kenya, dans le comté de Turkana. Il soutient que la production discursive 
du réfugié comme sujet immoral non seulement a des effets pratiques s'agissant des actions des agents de l'État et des travailleurs humanitaires, mais aussi ravive une cartographie coloniale binaire du monde divisée entre espaces « civilisés » et « non civilisés ». Ces imaginaires sociaux et discours banals illustrent le fait que le camp n'a pas seulement une géographie politique, mais aussi une géographie imaginative. Le camp de Kakuma est par là-même exclu à double titre : exclu de la modernité que l'humanitarisme est censé incarner et exclu de la communauté morale imaginée du Kenya. 